\title{
ArcheoSciences
}

Revue d'archéométrie

\section{Efficient, large-scale archaeological prospection using a true 3D GPR array system}

Immo Trinks, Jaana Gustafsson, Jesper Emilsson, Christer Gustafsson, Bernth Johansson and Johan Nissen

\section{(2) OpenEdition}

12 Journals

\section{Electronic version}

URL: https://journals.openedition.org/archeosciences/1857

DOI: $10.4000 /$ archeosciences. 1857

ISBN: 978-2-7535-1599-4

ISSN: $2104-3728$

Publisher

Presses universitaires de Rennes

\section{Printed version}

Date of publication: 30 October 2009

Number of pages: $367-370$

ISBN: 978-2-7535-0943-6

ISSN: 1960-1360

\section{Electronic reference}

Immo Trinks, Jaana Gustafsson, Jesper Emilsson, Christer Gustafsson, Bernth Johansson and Johan Nissen, "Efficient, large-scale archaeological prospection using a true 3D GPR array system", ArcheoSciences [Online], 33 (suppl.) | 2009, Online since 30 October 2011, connection on 01 February 2022. URL: http://journals.openedition.org/archeosciences/1857 ; DOI: https://doi.org/10.4000/ archeosciences. 1857 


\title{
Efficient, large-scale archaeological prospection using a true 3D GPR array system
}

\author{
Immo Trinks*, Jaana Gustafsson **, Jesper Emilsson ${ }^{* *}$, Johan Friborg ${ }^{* *}$, \\ Christer Gustafsson ${ }^{* *}$, Bernth Johansson ${ }^{* *}$ and Johan Nissen **
}

Key words: GPR, MIRA, 3D, Birka, Sweden.

\section{INTRODUCTION}

Many case studies in the past have shown that non-destructive GPR prospection can be used successfully to generate high-resolution images of the subsurface. The method can be of great value both to pin-point areas for future excavations and to gain information of areas where digs may be fruitless or should be avoided in order to protect the buried structures. However, traditional archaeological GPR prospection covering large areas generally is both time consuming and expensive.

Over the last years attempts for increased efficiency and resolution of GPR measurements through the use of parallel 2D measurements (Pipan et al., 1999; Whiting et al., 2001; Neubauer, 2001; Leckebusch, 2005; Seren et al., 2004) have been observed. The collection of 2D GPR sections with dense cross-line spacing and their exact positioning is time consuming (Leckebusch and Peikert, 2001; Slob et al., 2003). To overcome this several antennas can instead be used precisely positioned in multi-channel antenna arrays as demonstrated by both operators (Leckebusch, 2005) and GPR system manufacturers. To achieve full-resolution 3D imaging (without aliasing the data) the individual channel spacing should however not exceed $1 / 4$ of the wavelength of the antennas centre frequency (Grasmueck et al., 2005).

In May 2008 the GPR manufacturer Mala Geoscience $A B$ in collaboration with the archaeological prospection unit of the Swedish National Heritage Board conducted a large scale archaeological prospection study using the new Mala Imaging Radar Array (MIRA). This array system is defined by 1) closely spaced channels, 2) free combination of transmitter and receiver antennas, 3) near-identical antenna responses and 4) precise positioning. The purpose of this pilot study was to test the performance of this array GPR system in practice at a site where well expressed archaeological structures are known to exist in the ground.

\section{The MalÅ Imaging Radar ArRay (MIRA)}

The MIRA standard system consists of 17 GPR antennas $(400 \mathrm{MHz})$ positioned in two overlapping rows of 9 transmitter and 8 receiver antennas. The MIRA system can be equipped with up to 16 transmitters and 15 receiver antennas. Aside from the $400 \mathrm{MHz}$ system, antennas of $200 \mathrm{MHz}$ or $1.3 \mathrm{GHz}$ are available. Each receiver antenna is recording signals of two adjacent transmitter antennas, resulting in case of the $400 \mathrm{MHz}$ antenna system in 16 channels with a cross-line trace spacing of $8 \mathrm{~cm}$ (Fig. 1), corresponding to $1 / 4$ of the wavelength.

The 16 channel system covers a $128 \mathrm{~cm}$ wide swath for each driven track. In-line GPR trace sampling was set to $8 \mathrm{~cm}$ with a trace stacking factor of 4 . The antenna array is placed in a box mounted ahead of a motorized front mower

* Swedish National Heritage Board, Archaeological Excavation Department (immo.trinks@raa.se).

** Mala Geoscience AB. (jaana.gustafsson@malags.se), (bernth.johansson@malags.se). 


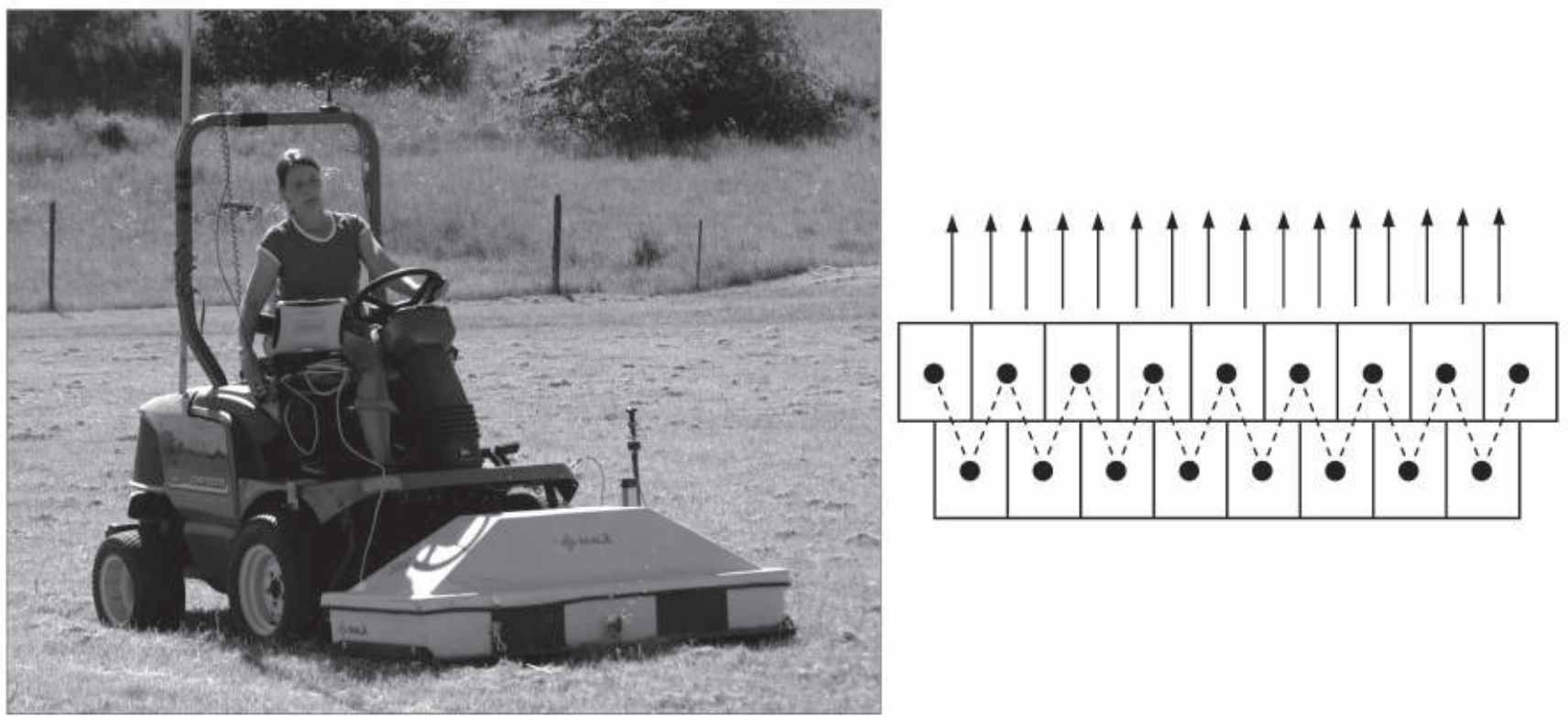

Figure 1: The MIRA mounted in front of a front mower. The prism for positioning using a total station is seen next to the yellow antenna box. The box contains an array of 17 antennas as shown in the sketch (right). Dotted lines indicate transmitter and receiver antenna combinations and arrows the 16 different channels (profiles) measured in one survey swath.

with hydraulic lift (Fig. 1). Power supply and a field computer for data collection are provided on the vehicle.

Accurate positioning of the GPR measurements is crucial. For this purpose a total station was used (RTK-GPS is also applicable). The position information from the total station is transferred via radio link to the measurement vehicle where the information is recorded together with the GPR data. The total station prism is mounted on the antenna array (Fig. 1). For orientation of the individual swaths a spray paint maker device is used to mark the start- and endpoints as well as the course of individual profiles.

The GPR and positioning data from the MIRA system is directly handled in the rSlicer software avoiding complicated and time consuming import routines. This software allows the pre-processing, interpolation, coordinate system transformation and 3D migration of the GPR data, followed by interactive interpretation of the observed features. The results can be printed and exported as geo-referenced TIFF- or DXF-files.

\section{DESCRIPTION OF THE SURVEY SITE AND FIELDWORK}

The test survey took place at the site of the Viking age town and trading place Birka on the island of Björkö in Lake Mälaren. Birka is believed to have been Sweden's first town, existing between 790 and $970 \mathrm{AD}$. After the town had been abandoned the place has remained largely undisturbed, except of some agricultural land use. Underneath the uppermost plough layer a cultural layer of up to 2 metres thickness in central parts of the town, containing Viking age structures, can be expected to extend across an area of 15 to 20 hectares, the so called Black Earth. Scientifically documented archaeological excavations have been conducted over an area covering less than $1 \%$ of the entire town area. In 2006 a single channel GPR test survey had been conducted at Birka resulting in the detection of several well expressed archaeological structures (Trinks et al., 2007).

Parallel swaths of up to $170 \mathrm{~m}$ length were measured in one direction at a speed of approximately $4 \mathrm{~km} / \mathrm{h}$. A flat, even and smooth ground would permit higher survey speeds of up to approximately $19 \mathrm{~km} / \mathrm{h}$ with the same settings. Generally it is the site conditions (surface roughness, obstacles preventing straight lines, crossing traffic etc.) which practically limit the survey speed. In grass the vehicle tracks where clearly visible and permitted in combination with degradable colour spray paint markers a good guidance to achieve complete area coverage. Successive profiles were measured with a small overlap in order to avoid gaps in the data.

In order to generate a base map over the survey area, point and line features in the surroundings were directly mapped in the data acquisition software and subsequently used during data processing. 


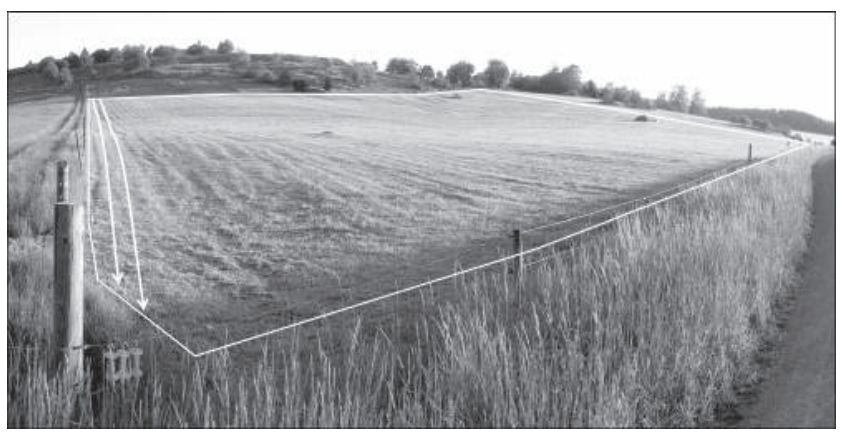

Figure 2 View of the survey area. The extent of the GPR survey area covering three hectares is marked with a white line. The first two MIRA survey tracks are indicated with arrows.

Within 5 hours we recorded 56 survey swaths covering $150 \mathrm{~m}$ by $62 \mathrm{~m}$ with an in-line and cross-line trace spacing of $8 \mathrm{~cm}$, corresponding to 134.4 line kilometres. Two surveyors using a manually operated single antenna with $25 \mathrm{~cm}$ cross-line and $5 \mathrm{~cm}$ in-line trace spacing would, in comparison, cover an area of $50 \mathrm{~m}$ by $50 \mathrm{~m}$ within the same time (in total 10 line $\mathrm{km}$ ).

Over the course of three days an interconnected area covering three hectares was surveyed in the Black Earth area of Birka. The processing of this amount of data was done during two days, resulting in geo-referenced times-slices.

\section{Results ANd Conclusions}

The novel MIRA system used in this investigation permitted the discovery and mapping of a considerable number of archaeologically interesting features of the Black Earth at Birka in unprecedented resolution. Since large excavations in this specific area are prohibitively expensive and in their nature destructive to the archaeological site, the pilot survey has resulted in valuable new archaeological information of hitherto unseen quality which otherwise would not have been obtainable. The large amount of data posses challenges in regard to data handling and interpretation. The data covering an area of approximately three hectares will be analysed in more detail, but already at a first glance several housing areas, tracks, and parts of the older city wall have been revealed in the generated high-resolution time slices (see example in Fig. 3).

A considerable increase in both GPR survey speed (16 fold or more) and sampling density compared to single channel measurements has been demonstrated. The laborious setup of survey grids and placement of profile lines on the ground is superseded by the use of a total station or RTK-GPS.

\section{References}

Grasmueck, M., Weger, R., Horsmeyer, H., 2005. Full-resolution 3D GPR imaging. Geophysics 70: K12-K19

LeCKebUSCH, J., 2005. Use of antenna arrays for GPR surveying in archaeology. Near Surface Geophysics, 3: 107-115.

Leckebusch, J., Peikert, R., 2001. Investigating the true resolution and three-dimensional capabilities of ground-penetrating radar data in archaeological surveys: measurements in a sand box. Archaeological Prospection, 8: 29-40.

Neubauer, W., 2001. Images of the invisible - prospecting methods for the documentation of threatened archaeological sites. Naturwissenschaften, 88: 13-24.

Neubauer, W., Eder-Hinterleitner, A., Seren, S., Melichar, P., 2002. Georadar in the Roman Civil Town Carnatum, Austria:

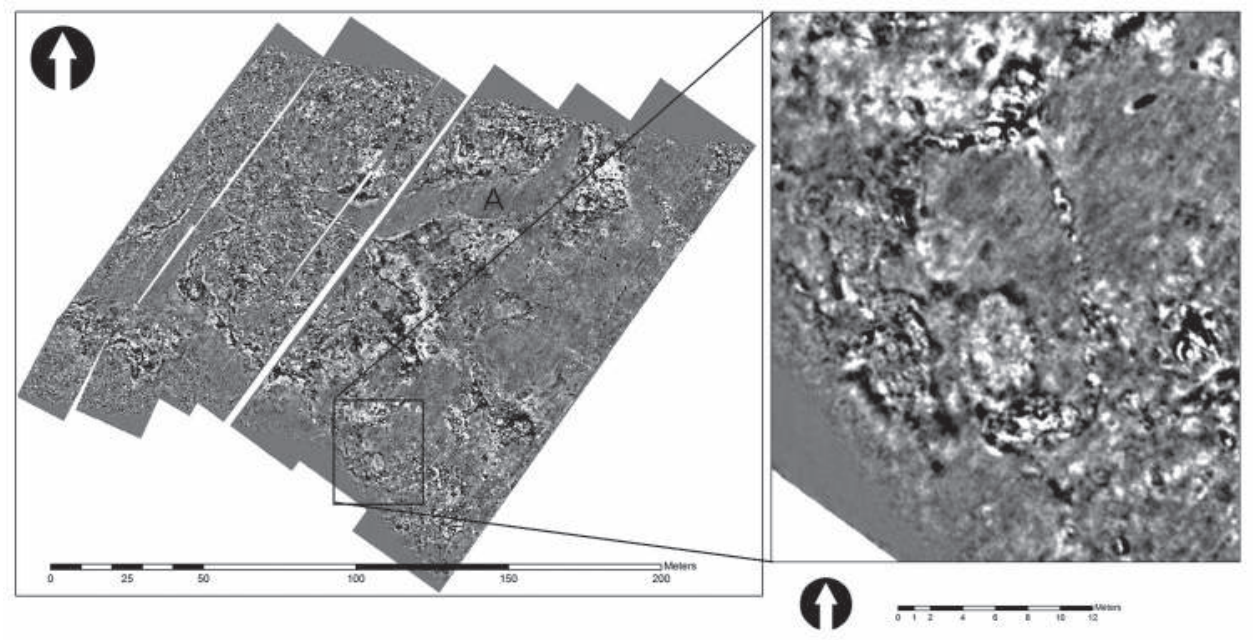

Figure 3:

Left: Overview of the investigated area. A town rampart is marked with A.

Right: detail of a depth-slice at approximately $0.5 \mathrm{~m}$ depth showing a Viking age house measuring $20 \mathrm{~m}$ by $9 \mathrm{~m}$ with curved side walls. Internal structures can be seen inside the house. In the very high resolution data reflections from small stones associated with individual postholes are visible. 
An approach for archaeological interpretation of GPR data. Archaeological Prospection, 9: 135-156.

Pipan, M., Baradello, L., Forte, E., Prizzon, A. and Finetti, I., 1999. 2-D and 3-D processing and interpretation of multi-fold ground penetrating radar data: a case history from an archaeological site. Journal of Applied Geophysics 41: 271-292.

Seren, S., Eder-Hinterleitner, A., Neubauer, W. and Groh, S., 2004. Combined high-resolution magnetics and GPR surveys of the roman town of Flavia Solva. Near Surface Geophysics 2: 63-68.

Slob, E. C., Groenenboom, J. and Fokкema, J. T., 2003. Automated acquisition and processing of 3D GPR Data for object detection and characterization. Subsurface Sensing Technologies and Applications, 4(1): 5-18.
Trinks, I., Larsson, L. I. and Eder-Hinterleitner, A., 2007. Mapping of Sweden's first town Birka using georadar and magnetometer prospection. ŠTUDIJNÉ ZVESTI ARCHEOLOGICKÉ ÚSTAVU SAV, 41: 245-246.

Trinks, I., Nissen, J., Johansson, B., Emilsson, J., Gustafsson, C., Friborg, J. and Gustafsson, J. 2008. Pilot study of the new multichannel GPR system MIRA for large scale, highresolution archaeological prospection at the site of the Viking town Birka in Sweden. Newsletter of the International Society for Archaeological Prospection, 16: 4-7.

Whiting, B. M., McFarland, D. P. and Hackenberger, S., 2001. Three-dimensional GPR study of a prehistoric site in Barbados, West Indies. Journal of Applied Geophysics, 47: 217-226. 